\title{
Plio-Pleistocene Plant Megafossils from the Lukundol Formation (Nakkhu Khola, Lalitpur District, Central Nepal)-First Results
}

\author{
Khum N. Paudayal \\ Central Department of Geology \\ Tribhuvan University, Kirtipur, Kathmandu, Nepal \\ E-mail:khum99@gmail.com
}

\begin{abstract}
The lacustrine sediments of the Kathmandu Basin are rich in plant mega and micro fossils. The Lukundol Formation which is distributed in the southern part of the Kathmandu Basin yielded nicely preserved plant megafossils from different locations. A $5.5 \mathrm{~m}$ thick carbonaceous clay bed at the left bank of the Nakkhu Khola, near Chyasikot village, Lalitpur contains abundant plant debris, leaf impressions, seed and fruits, gymnosperm needles and cones. The plant fossils discovered from this location are identified as Berberis asiatica (leaf), Rhododendron arboreum (leaf), Rhododendron barbatum (leaf), Litsea elongata (leaf), Pinus roxburghii (needles and cones) Trapa bispinosa and Trapa quadrispinosa (fruits). Many leaf impressions are also collected from Bungmati and Chovar area. This paper deals with the first reporting of plant fossils from Nakkhu Khola section. The findings from other sections will be reported separately.
\end{abstract}

Key words: Plio-Pleistocene, Plant megafossils, Lukundol Formation, Kathmandu Basin

\section{INTRODUCTION}

The Lukundol Formation is the oldest lacustrine sediments distributed in the southern part of the Kathmandu Valley. It is well exposed along Nakkhu Khola, Bagmati River, Harkate Khola and Kodku Khola sections. The total thickness of this formation along the Khahare Khola near Lukundol village is $205 \mathrm{~m}$. It consists of conglomerate with minor amount of sand and clay lenses at the basal part. The conglomerate beds are named differently by different authors e.g. Basal Boulder Beds (Shrestha, 1998), Tarebhir Formation (Sakai 2001). The conglomerate beds are followed by thick beds of black to grey organic clay, silt and sand. There are frequent lignite layers found in association with organic clay beds. The top part consists of alternative beds of clay and gravels and the uppermost part is covered by very thick gravel beds. In Nakkhu and Bagmati Rivers, the thickness of exposures varies from few meters to few tens of meters in the river bank terraces. The age of Lukundol Formation ranges from the Gaus Chron to the early Brunhes Chron i.e. Late Pliocene to Early Pleistocene (Yoshida \& Gautam 1988). The Lukundol Formation yielded many vertebrate fossils (Sharma 1974, West \& Munthe 1981, West et al. 1988, Sah et al. 1995), mollucan fossils (Gurung et al. 2001), pollen and spores (Yoshida \& Igarashi 1984, Igarashi et al. 1988, Bhandari \& Paudayal 2007) but there is no plant megafossils reported from this formation so far. This paper deals with some plant megafossils discovered from the Lukundol Formation at the left bank of Nakkhu
Khola, near Chyasikot, Lalitpur.

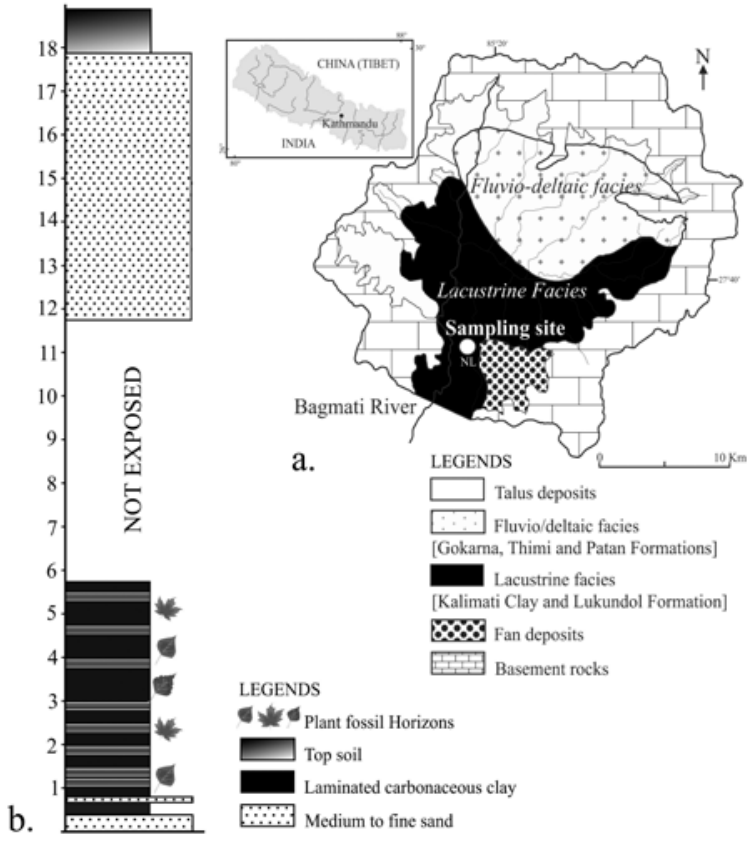

Fig. 1. (a) Geology of the Kathmandu Basin (with fossil location in the white circle), modified after Sakai (2001), (b) Lithostratigraphical details of the Lukundol Formation exposed at the left bank of Nakkhu Khola near Chyasikot, Lalitpur. 


\section{MATERIAL AND METHODS}

The sampling location lies at the left bank of Nakkhu Khola (co-ordinates $27^{\circ} 37^{\prime} 55.45^{\prime \prime} \mathrm{N}$ and $85^{\circ} 18^{\prime} 25^{\prime \prime} \mathrm{E}$, altitude $1320 \mathrm{~m}$ amsl). The exposure is $18.93 \mathrm{~m}$ thick consisting of medium to fine sand, silt, silty clay and carbonaceous clay. The lower part of the exposure $(5.5 \mathrm{~m}$ from the river bed) is carbonaceous clay rich in plant megafossils while the middle part is covered by vegetation and the upper part is highly weathered sand. The bottom part was found to be good for the sampling of plant mega-fossils. The plant fossils were collected by splitting the clay and silt laminations with common knife. It was quite easy to split the faintly indurated claystones and siltstones through the interface of parallel laminations. The fossils were carefully wrapped in newspapers and placed inside the polyethylene sample bags with proper labeling and brought to the Central Department of Geology, Tribhuvan University, Nepal for further cleaning and processing. High resolution photographs were taken with NIKON D-5200 digital camera with proper scaling and orientation. After this the fossils and photographs were carried to Birbal Sahni Institute of Palaeobotany, (Lucknow, India) for further determination. The fossils were brought back and stored at Central Department of Geology Museum after identification.

\section{RESULTS}

Altogether 7 species of plant fossils belonging to five families are identified to lower taxonomic level. They are listed below.

Locality: Chyasikot, Left bank of Nakkhu Khola, Lalitpur

1. Material: Leaf (Plate 1, Fig. 1)

Family: Berbridaceae

Genus: Berberis

Species: asiatica

Binomial name: Berberis asiatica Roxb. ex DC.

2. Material: Leaf (Plate 1, Fig. 2)

Family: Ericaceae

Genus: Rhododendron

Species: arboreum

Binomial name: Rhododendron arboreum $\mathrm{Sm}$.

3. Material: leaf (Plate 1, Fig. 3a,b)

Family: Ericaceae

Genus: Rhododendron

Species: barbatum

Binomial name: Rhododendron barbatum Wallich ex G. Don
4. Material: leaf (Plate 1, Fig. 4a,b)

Family: Lauraceae

Genus: Litsea

Species: elongata

Binomial name: Litsea elongata (Nees) J. D. Hooker

5. Material: Needle (Plate 1, Fig. 5a)

Family: Pinaceae

Genus: Pinus

Species: roxburghii

Binomial name: Pinus roxburghii Sarg.

6. Material: Cone (Plate 1, Fig. 5b)

Family: Pinaceae

Genus: Pinus

Species: roxburghii

Binomial name: Pinus roxburghii Sarg.

7. Material: Fruit (Plate 1, Fig. 6a)

Family: Trapaceae

Genus: Trapa

Species: bispinosa

Binomial name: Trapa bispinosa Roxb.

8. Material: Fruit (Plate 1, Fig. 6b)

Family: Trapaceae

Genus: Trapa

Species: quadrispinosa

Binomial name: Trapa quadrispinosa Roxb.

\section{CONCLUSION}

The Lukundol Formation which constitutes the bottom part of Kathmandu Lake sediments is rich in plant fossils. Plant debris, leaves, cones, fruit and seeds are collected from the Nakkhu Khola area, near Chyasikot, Lalitpur. At least seven species of plant fossils were identified to lower taxonomic level. Plenty of macrophyte such as Trapa indicate the lake was shallow and they also indicate the eutrophication condition. Berberis asiatica is a shrub growing in rocky dry northern slopes in modern environment while Rhododendron and Litsea grow together in temperate forests. Pinus roxburghii grows in subtropical to lower temperate ecological zone. The fossil assemblages broadly suggest subtropical to lower temperate climate existed during late Pliocene-early Pleistocene time in and around Kathmandu Valley.

\section{ACKNOWLEDGEMENTS}

I would like to thank Dhan Bahadur Khatri for field assistance, Dr. Gaurav Srivastava (Birbal Sahni Institute of Palaeobotany, Lucknow, India) for helping in the identification of fossil taxa and Prof. Lalu Paudel for providing necessary facilities to conduct this research at Central Department of Geology, Kirtipur, Nepal. 
Khum N. Paudayal
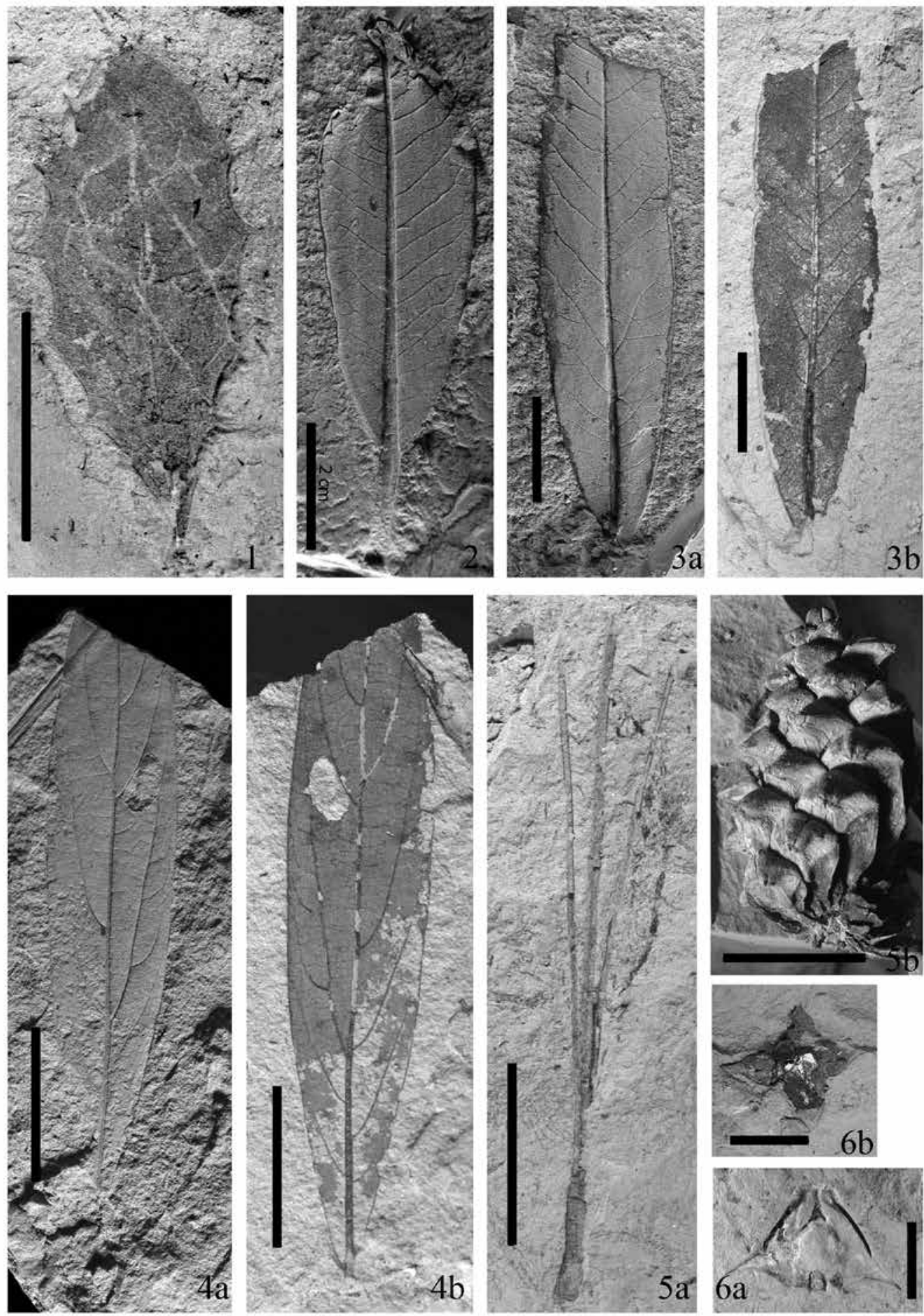

Plate 1. (1). Berberis asiatica (leaf), (2). Rhododendron arboreum (leaf), (3a). Rhododendron barbatum (leaf), (3b). Counterpart of the same leaf, (4a). Litsea elongata (leaf), (4b). Counterpart of the same leaf, (5). Pinus roxburghii (needles), (5b). Pinus roxburghii (cone), (6a). Trapa bispinosa (fruit), (6b). Trapa quadrispinosa (fruit), Scale bar $=2 \mathrm{~cm}$. 


\section{REFERENCES}

Bhandari, S. and Paudayal, K. N. 2007. Palynostratigraphy and palaeoclimatic interpretation of the PlioPleistocene Lukundol Formation from the Kathmandu Valley, Nepal. Jour. Journal of Nepal Geological Society 35 : 1-10.

Gurung, D., Takayasu, K., Nesemann, H. 2001. Preliminary study of fossil freshwater molluscs from the Plio-Pleistocene Kathmandu Basin sediments, central Nepal. Journal of Nepal Geological Society 25 (Sp. Issue): 81-88.

Igarashi, Y., Yoshida, M., and Tabata, H. 1988. History of Vegetation and Climate in the Kathmandu Valley. Proceedings of Indian Natural Science Academy 54A(4) : 550-563.

Sah, R.B., Paudel, M. and Ghimire, D. 1995-96. Lithological successions and some vertebrate fossils from the fluviolacustrine sediments of the Kathmandu Valley, Central Nepal. Nahson Bulletin 5-6: 21-27.

Sakai, H. 2001. Stratigraphic division and sedimentary facies of the Kathmandu Basin Group, central Nepal. Journal of Nepal Geological Society 25: 19-32.

Sharma, C.K. 1973. Geology of Nepal, Man Ram Sharma, Kathmandu, Nepal.
Shrestha, O.M., Koirala, A., Karmacharya, S. L., Pradhananga, U.B., Pradhan, R. and Karmacharya, R. 1998. Engineering and environmental geolological map of the Kathmandu Valley $(1: 50,000)$. Department of Mines and Geology, HMG Nepal.

West, R.M. and Munthe, J. 1981. Neogene vertebrate Palaeontology and Stratigraphy of Nepal. Journal of Nepal Geological Society 1: 1-14.

West, R.M., Dongol, G.M.S., Munthe, J., Hutchinson, J.H. and Gupta, V.J. 1988. Late Neogene and Quaternary Geology, Palaeontology and Palaeoenvironment of the Kathmandu Valley, Central Nepal and the Churia Hills, Western Nepal. In The Palaeoenvironment of East Asia from the Mid-Tertiary, Proceedings of the Second Conference (Ed. P. Whyte) II: 916-936.

Yoshida, M. and Gautam, P.1988. Magnetostratigraphy of Plio-Pleistocene lacustrine deposits in the Kathmandu Valley, central Nepal. Proceedings of Indian Natural Science Academy 54A(30): 410-417.

Yoshida, M. and Igarashi, Y. 1984. Neogene to Quaternary Lacustrine sediments in the Kathmandu Valley, Nepal. Journal of Nepal Geological Society 4: 73-100. 